\title{
PEMBAGIAN PERAN, TINGKAT INTERAKSI SUAMI-ISTRI SERTA PENGARUHNYA TERHADAP INDEKS KEBAHAGIAAN KELUARGA PETANI PADA DUA MASA
}

\author{
Larasati Nadhifah ${ }^{1}$, Herien Puspitawati ${ }^{1}$, Defina $\left.{ }^{1 *}\right)$ \\ ${ }^{1}$ Departemen IImu Keluarga dan Konsumen, Fakultas Ekologi Manusia, \\ IPB University, Bogor 16680, Indonesia.
}

*)Email: defina@apps.ipb.ac.id

\begin{abstract}
Abstrak
Data BPS untuk tiga tahun terakhir menunjukkan bahwa petani Indonesia sudah sejahtera dengan nilai tukar petani mencapai $>100$. Tujuan penelitian ini adalah menganalisis pengaruh peran gender dan interaksi suami-istri terhadap indeks kebahagiaan keluarga petani. Pendekatan penelitian adalah kuantitatif dengan desain crosssectional study. Pengumpulan data primer menggunakan teknik wawancara melalui kuesioner. Pada penelitian ini, sampel dipilih secara purposive di Kecamatan Pamijahan, Kabupaten Bogor, Provinsi Jawa Barat. Kriteria suami adalah bekerja sebagai petani padi sawah serta istri bekerja yang menghasilkan uang. Jumlah sampel 70 orang. Hasilnya, kategori untuk variabel peran gender, interaksi suami-istri, serta indeks kebahagiaan keluarga petani adalah sedang. Ada perbedaan peran gender serta interaksi suami-istri keluarga petani setiap masanya. Data uji regresi menunjukkan bahwa ada pengaruh usia suami, pendapatan per kapita keluarga, serta interaksi suami-istri terhadap indeks kebahagiaan keluarga petani. Semakin tinggi usia suami, semakin besar pendapatan per kapita dan semakin intens interaksi suami-istri, semakin sejahtera keluarga petani. Implikasi penelitian adalah perlunya peningkatan indeks kebahagiaan petani melalui peningkatan pendapatan per kapita dan interaksi keluarga khususnya interaksi antara suami dan istri.
\end{abstract}

Kata kunci: indeks kebahagiaan, interaksi suami-istri, masa tanam, masa tunggu, peran gender

\section{Sharing of Roles, Level of Husband-Wife Interaction and Its Effect on Happiness Index Family Farmers in Two Times}

\begin{abstract}
BPS data for the last three years show that Indonesian farmers are already prosperous, with farmer exchange rates reaching $>100$. This study aimed to analyze the influence of gender roles and husband-wife interaction on the happiness index of the farmer family. The research approach was quantitative with a cross-sectional study design. Primary data were collected through interview techniques using a questionnaire. In this study, the sample was selected purposively in Pamijahan District, Bogor Regency, West Java Province. The criteria for the husband is working as a rice farmer and for the wife is earning money. The number of samples was 70 people. As a result, the variable gender roles, husband-wife interactions, and the farmer family happiness index were moderate. There were differences in gender roles and husband-wife interactions of farming families at each time. The regression test data shows an effect of husband's age, family per capita income, and husband-wife interaction on the farmer family happiness index. The higher the husband's age, the higher the income per capita and the more intense the husband-wife interaction, the more prosperous the farming family will be. The implication of the research is the need to increase the farmer's happiness index through increasing per capita income and family interactions, especially interaction between husband and wife.
\end{abstract}

Keywords: gender roles, happiness index, husband-wife interaction, planting season, waiting season

\section{PENDAHULUAN}

Produksi gabah memberikan kontribusi besar pada sektor pertanian di Indonesia. Provinsi Jawa Barat berada pada posisi ke-3, sedangkan posisi pertama dan kedua adalah Provinsi Jawa Timur dan Jawa Tengah, yakni 1,61 juta ha (2020) (BPS, 2021a). Selanjutnya, luas lahan tanam padi terluas di Jawa Barat adalah Indramayu, yakni 236.054 ha, sedangkan luas tanam padi di Kabupaten Bogor mencapai 61.829 ha (BPS Jabar, 2018). Di Kabupaten Bogor, tiga wilayah berturut-turut dengan luas tanam padi adalah Kecamatan Jonggol (9.525 ha), Sukamakmur (8.645 ha), dan Kecamatan Pamijahan (7.198 ha) (BPS Kab Bogor, 2019). Lebih lanjut, kontribusi yang besar dari produksi gabah tidak terlepas dari 
peran sebagian penduduk Indonesia yang banyak berprofesi sebagai petani. Peran mereka yang besar itu perlu mendapatkan perhatian, terkhusus berkaitan dengan kesejahteraannya. Sementara itu, belum atau sudah sejahteranya petani di Indonesia diukur berdasarkan Nilai Tukar Petani (NTP), yakni dengan nilai >100 yang berarti sudah sejahtera. Namun, data NTP tanaman pangan pada 2019 menunjukkan terdapat tiga bulan yang memiliki nilai NTP <100, yakni pada Mei, Juni, dan Juli. Hal itu berarti petani belum sejahtera (BPS, 2021b).

Keumala dan Zainuddin (2018) mengungkapkan bahwa NTP naik tidak selalu bermakna baik. Temuannya, petani menjual gabah dengan harga sangat murah karena mereka dieksploitasi oleh pemilik modal dan adanya pinjaman berbunga. Pendapatan petani yang rendah membuat petani harus berhutang untuk memenuhi kebutuhannya (Suryadi \& Fathurrahman, 2019; Suryandari \& Rahayuningsih, 2020). Tingginya nilai tukar petani ternyata tidak menjamin bahwa petani sudah sejahtera karena dari lima indikator, di antaranya pendapatan-pengeluaran serta keragaan tingkat ketahanan pangan dalam rumah tangga petani, nyatanya, tingkat kesejahteraan petani masih rendah (Matina \& Praza, 2018).

Alfrida dan Noor (2018) mengungkapkan bahwa masih terdapat keluarga petani padi sawah yang termasuk kategori keluarga miskin atau tidak sejahtera. Dengan menggunakan indikator ekonomi, dianalisis tingkat kesejahteraan rumah tangga petani padi sawah. Artinya, keluarga petani padi sawah masih banyak yang belum sejahtera. Menurut data pemerintahan tentang tingkat kebahagiaan penduduk Indonesia, indeks kebahagiaan Jawa Barat berada di bawah rata-rata indeks kebahagiaan yang dimiliki Indonesia. Berdasarkan data BPS Jabar (2017) diketahui indeks kebahagiaan penduduk Jawa Barat tahun 2017 mencapai 68,91 dan angka ini masih di bawah angka nasional $(70,69)$. Bahkan, posisi indeks kebahagiaan Provinsi Jawa Barat dari 34 provinsi adalah ke-30. Pada dimensi kepuasan hidup, indeks indikator tertinggi adalah keharmonisan keluarga, sedangkan indeks indikator terendah adalah pendidikan dan keterampilan.

Kesejahteraan keluarga petani, menurut Sunarti dan Khomsan (2006), menjadi bagian dari tujuan pembangunan pertanian serta pembangunan nasional. Pencapaian kesejahteraan anggota keluarga merupakan perjuangan setiap keluarga. Keluarga petani dapat dikatakan telah sejahtera apabila telah mampu memenuhi kebutuhan dasar anggota keluarganya. Subjective well-being atau 'kesejahteraan subjektif' sering digunakan secara bergantian dengan istilah happiness atau 'kebahagiaan.' Lebih lanjut, Williams, Sawyer, dan Wahlstrom (2009) mengungkapkan bahwa kebahagiaan adalah perwujudan dari kesempurnaan sehingga berbagai upaya dilakukan orang untuk meraihnya. Artinya, setiap manusia berkeinginan untuk mencapai kebahagiaan dan akan terus berupaya dengan berbagai cara untuk meraih kebahagiaan tersebut dalam hidupnya. Sama halnya dengan banyak keluarga petani yang masih belum sejahtera dan tentu ingin sejahtera.

Selain dambaan kehidupan yang sejahtera, keluarga petani di desa pun diharapkan dapat memiliki interaksi antaranggota keluarga yang baik. Interaksi dalam keluarga berkaitan dengan keharmonisan keluarga (Wheatley, 2014). Lebih lanjut dikatakan bahwa jika interaksi dalam keluarga rendah, suasana dalam keluarga tidak harmonis. Tidak hanya itu, rendahnya interaksi dalam keluarga juga dapat memengaruhi cara pengambilan keputusan dalam keluarga. Padahal, cara pengambilan keputusan akan baik jika semua anggota keluarga dilibatkan. Dalam berinteraksi, semua anggota keluarga akan mendiskusikan suatu hal untuk memperoleh solusi terbaik. Mereka akan bersepakat sehingga konflik dalam keluarga dapat dicegah. Salah satu interaksi dalam keluarga adalah antara suami dengan istrinya. Dalam keluarga, interaksi antara suami dengan istri dapat menjadi sebuah interaksi positif ataupun negatif.

Penelitian khusus tentang interaksi suami-istri pernah diteliti oleh Herawati et al. (2018), namun keluarga yang diteliti bukan keluarga petani. Hasilnya, kualitas perkawinan dipengaruhi oleh interaksi keluarga. Selanjutnya, penelitian tentang pembagian peran gender pada keluarga petani sudah pernah diteliti oleh Puspitawati dan Fahmi (2008). Temuannya, ada tiga hal yang memengaruhi pembagian peran gender: 1) penghasilan per kapita per bulan, 2) kekerapan perencanaan, serta 3) adanya permasalahan umum dalam keluarga.

Penelitian lainnya mengungkapkan bahwa dalam usaha tani, hal yang memengaruhi pembagian peran gender, yaitu 1) banyaknya tanggungan keluarga, 2) kekerapan perencanaan, serta 3) masalah yang umum 
dalam keluarga. Selanjutnya, Puspitawati et al. (2019) mengungkapkan bahwa terdapat tiga faktor yang memengaruhi kualitas pernikahan buruh tani "brondol" bawang dan keluarga nelayan, berdasarkan urutan kekuatan koefisien regresi, yakni: 1) relasi atau hubungan gender, 2) penghasilan per kapita, serta 3) ketahanan sebuah keluarga. Sebaliknya, Nurlian dan Daulay (2008) mengungkapkan bahwa sebenarnya dalam keluarga petani ladang telah ada pembagian peran antara suami dengan istri. Pembagian peran antara suami dengan istri juga ada dalam keluarga petani yang menanam bawang, terutama untuk dimensi publik atau pekerjaan di ladang (Samay, Susanti, \& Romano, 2020).

Berdasarkan uraian tersebut, petani padi sudah sejahtera berdasarkan standar NTP $>100$. Namun, dari penelitian-penelitian terdahulu diketahui bahwa berdasarkan kriteria lainnya, masih ada petani yang belum tergolong sejahtera dan harus berhutang sebagai salah satu strategi bertahan hidup. Penelitian tentang interaksi suami-istri dalam keluarga petani, khususnya petani padi, belum ada. Begitu pun dengan adanya peran gender yang dibagi dalam ranah rumah tangga (domestic), publik, serta sosial-kemasyarakatan, juga masih sulit ditemukan, sedangkan kebahagian keluarga petani padi akan dapat tercapai jika kesejahteraan dan interaksi dalam keluarga tercapai serta pembagian peran yang baik.

Penelitian ini bertujuan untuk menganalisis aspek pengaruh peran gender serta interaksi antara suami dan istri terhadap indeks kebahagiaan pada keluarga petani padi. Tujuan secara khusus adalah mengidentifikasi karakteristik keluarga petani, pembagian peran gender dan interaksi suami-istri pada keluarga petani, indeks kebahagiaan keluarga petani, serta menganalisis uji pengaruh karakteristik keluarga, peran gender, dan interaksi suamiistri terhadap indeks kebahagiaan keluarga petani.

\section{METODE}

Penelitian ini menggunakan pendekatan kuantitatif dengan desain cross-sectional study. Pemilihan lokasi penelitian menggunakan teknik puprposif dengan kriteria penghasil padi sawah terbesar di Kabupaten Bogor. Lokasi penelitian ini adalah Kecamatan Pamijahan dan melibatkan dua desa, yaitu Desa Ciasmara dan Desa Ciasihan. Penelitian dilaksanakan selama lima bulan, yakni dari Desember 2018 sampai April 2019.
Dalam penelitian ini, populasinya ialah keluarga dengan suami berprofesi sebagai petani yang berada di Kecamatan Pamijahan. Responden penelitian merupakan istri yang memiliki pekerjaan dan menghasilkan uang. Purposif merupakan teknik penarikan contoh yang dilakukan, yakni suaminya dengan profesi petani padi sawah, sedangkan istrinya memiliki profesi dan penghasilan, berasal dari keluarga lengkap (suami-istri masih hidup), serta ada kesediaan menjadi responden. Jumlah contoh sebanyak 70 orang dan seluruhnya bermukim di lokasi yang sama. Penelitian ini memiliki tiga variabel utama, yaitu 1) peran gender, 2) interaksi suami-istri, dan 3) indeks kebahagiaan.

Peran gender adalah pendistribusian tugas untuk menjaga keefektifan serta keseimbangan sebuah sistem dalam keluarga dan masyarakat (Puspitawati, 2012). Peran gender ada dalam tiga ranah, yakni domestik, publik, dan sosialkemasyarakat. Alat ukur variabel peran gender adalah modifikasi kuesioner yang dikembangkan oleh Krzaklewska (2014) serta Puspitawati dan Herawati (2018). Pengukuran mengacu pada instrumen tersebut melibatkan 27 item pernyataan yang terdiri atas dimensi sebagai berikut: dimensi domestik (15 pernyataan), dimensi publik (5 pernyataan), dan dimensi sosial-kemasyarakatan (7 pernyataan). Instrumen ini memiliki nilai reliabilitas sebesar 0,683 . Penelitian ini menggunakan skala Likert dengan rentang nilai antara 1 sampai 6 (1 adalah suami saja, 2 adalah suami dominan, 3 adalah suami dan istri setara, 4 adalah istri dominan, 5 adalah istri saja, dan 6 adalah lainnya).

Interaksi antara suami dan istri adalah suatu hubungan yang bersifat timbal balik serta saling memengaruhi antara satu dengan lainnya (Puspitawati, 2012). Untuk menjalin sebuah hubungan diperlukan komunikasi. Komunikasi ini menurut Yeni (2013) merupakan faktor penting dalam hubungan manusia. Komunikasi antarpasangan hidup ialah interaksi suami-istri berupa saling memberi dan menerima informasi serta masukan. Variabel interaksi suami-istri adalah komunikasi dan kelekatan yang diukur berdasarkan konsep dimensi interaksi dari Puspitawati (2012) dan Chuang (2005). Ada 15 butir pernyataan yang terdiri atas dimensi sebagai berikut: dimensi komunikasi $(7$ pernyataan) dan dimensi kelekatan (8 pernyataan). Skalanya adalah skala Likert 4 poin (1=tidak pernah, 2=jarang, 3=sering, $4=$ selalu). Instrumen ini memiliki nilai reliabilitas sebesar 0,742 . 
Indeks kebahagiaan adalah sebuah ukuran yang mendeskripsikan tingkat kesejahteraan sebab kebahagiaan adalah cerminan dari tingkat kesejahteraan yang berhasil dicapai masing-masing individu (Kapteyn, Smith, \& Soest, 2010). Variabel indeks kebahagiaan diukur berdasarkan konsep kebahagiaan Hills dan Argyle (2002). Pengukuran indeks kebahagiaan dilakukan dengan memodifikasi instrumen The Oxford Happiness Questionnaire dan modifikasi dari Survei Peningkatan Tingkat Kebahagiaan 2017 oleh BPS (2017). Kuesioner terdiri dari 10 pernyataan dan 5 pernyataan untuk mengukur indeks kebahagiaan keluarga petani. Skala yang digunakan adalah skala Likert dengan 4 poin (satu berarti sangat tidak setuju, dua berarti tidak setuju, tiga berarti setuju, dan empat berarti sangat setuju) dengan nilai reliabilitas sebesar 0,644 .

Data dianalisis secara deskriptif dan inferensia. Analisis ini dilakukan menggunakan alat bantu SPSS 16,0 . Metode analisis statistik berupa analisis deskriptif digunakan untuk mengetahui gambaran variabel yang diteliti berupa nilai rata-rata, standar deviasi, nilai minimal, dan nilai maksimal dari sebaran data. Digunakannya analisis inferensia adalah untuk menemukan jawaban dari tujuan penelitian, yakni melalui uji regresi. Uji regresi digunakan untuk mengetahui pengaruh karakteristik keluarga, peran gender, serta interaksi suamiistri terhadap indeks kebahagiaan.

\section{HASIL}

\section{Karekteristik Keluarga Responden}

Usia serta Pendidikan Responden. Lebih dari separuh responden $(71,4 \%)$ berusia dewasa awal. Sebaliknya, kurang dari dari separuh suami $(45,7 \%)$ berusia dewasa awal. Jumlah suami terkategori dewasa akhir $(11,4 \%)$ lebih banyak daripada responden atau istri $(4,3 \%)$. Sementara itu, lebih dari separuh responden dan suami menamatkan sekolah dasar atau mengenyam pendidikan selama enam tahun. Dari semua responden, termasuk suaminya, masih ada yang tidak menyelesaikan pendidikan dasar (Tabel 1).

Besar Keluarga. Berdasarkan hasil penelitian, lebih dari setengah keluarga responden $(71,4 \%)$ tergolong keluarga dengan tipe keluarga kecil ( $\leq 4$ jiwa) dengan rata-rata besar anggota keluarga sebanyak lima jiwa. Selebihnya merupakan keluarga sedang $(17,1 \%)$ dan keluarga besar $(11,4 \%)$.
Lama Pernikahan. Berdasarkan hasil penelitian diketahui bahwa lama pernikahan keluarga responden terkategori rendah, sedang, dan tinggi. Pengkategorian tersebut merupakan hasil dari metode standar deviasi (emic) dari sebaran lama pernikahan keluarga. Rata-rata keluarga memiliki lama pernikahan selama 19,85 tahun. Keluarga dengan lama pernikahan kategori rendah memiliki proporsi terbanyak $(38,6 \%)$, lalu diikuti dengan kategori sedang $(37,1 \%)$, dan sisanya $(24,3 \%)$ merupakan kategori tinggi.

Profesi. Petani merupakan profesi dominan yang ditekuni oleh responden. Lebih dari setengah jumlah responden $(82,9 \%)$ dalam penelitian ini bekerja sebagai petani pada masa tanam. Sebaliknya, pada masa tunggu, lebih setengah $(71,4 \%)$ dari jumlah responden tidak memiliki pekerjaan. Profesi suami responden pada masa tanam adalah petani secara keseluruhan.

Tabel 1 Sebaran responden sesuai dengan usia, pendidikan istri-suami, nilai minimum-maksimum, rata-rata, serta standar deviasi

\begin{tabular}{|c|c|c|c|c|}
\hline \multirow{2}{*}{ Kategori } & \multicolumn{2}{|c|}{ Suami } & \multicolumn{2}{|c|}{ Istri } \\
\hline & $\mathrm{n}$ & $\%$ & $\mathrm{n}$ & $\%$ \\
\hline \multicolumn{5}{|l|}{ Umur (tahun) } \\
\hline $\begin{array}{l}\text { Dewasa awal (18-40 } \\
\text { tahun) }\end{array}$ & 32 & 45,7 & 50 & 71,4 \\
\hline $\begin{array}{l}\text { Dewasa madya ( } 41 \text { - } \\
60 \text { tahun) }\end{array}$ & 30 & 42,9 & 17 & 24,3 \\
\hline $\begin{array}{l}\text { Dewasa akhir (>60 } \\
\text { tahun) }\end{array}$ & 8 & 11,4 & 3 & 4,3 \\
\hline Total & 70 & 100 & 70 & 100 \\
\hline Min-maks (tahun) & \multicolumn{2}{|c|}{$25-74$} & \multicolumn{2}{|c|}{$19-66$} \\
\hline $\begin{array}{l}\text { Rata-rata } \pm S D \\
\text { (tahun) }\end{array}$ & \multicolumn{2}{|c|}{$44,20 \pm 12,48$} & \multicolumn{2}{|c|}{$38,39 \pm 11,47$} \\
\hline \multicolumn{5}{|l|}{$\begin{array}{l}\text { Lama Pendidikan } \\
\text { (tahun) }\end{array}$} \\
\hline $\begin{array}{l}\text { Tidak tamat SD (<6 } \\
\text { tahun) }\end{array}$ & 7 & 10,0 & 8 & 11,4 \\
\hline Tamat SD (6 tahun) & 46 & 65,7 & 49 & 70,0 \\
\hline $\begin{array}{l}\text { Tamat SMP }(9 \\
\text { tahun) }\end{array}$ & 11 & 15,7 & 10 & 14,3 \\
\hline $\begin{array}{l}\text { Tamat SMA (12 } \\
\text { tahun) }\end{array}$ & 5 & 7,1 & 2 & 2,9 \\
\hline $\begin{array}{l}\text { Tamat PT/Akademik } \\
\text { (>12 tahun) }\end{array}$ & 1 & 1,4 & 1 & 1,4 \\
\hline Total & 70 & 100,0 & 70 & 100,0 \\
\hline Min-maks & \multicolumn{2}{|c|}{$0-16$} & \multicolumn{2}{|c|}{$0-16$} \\
\hline Rata-rata $\pm S D$ & \multicolumn{2}{|c|}{$6,21 \pm 2,56$} & \multicolumn{2}{|c|}{$6,57 \pm 2,78$} \\
\hline
\end{tabular}

Penjelasan: $\mathrm{n}=$ jumlah responden; $\%=$ persentase responden 
Tabel 2 Sebaran responden berdasarkan penghasilan total keluarga per bulan, rata-rata, nilai minimummaksimum, serta standar deviasi

\begin{tabular}{|c|c|c|c|c|}
\hline \multirow{2}{*}{ Penghasilan } & \multicolumn{2}{|c|}{ Masa tanam } & \multicolumn{2}{|c|}{ Masa tunggu } \\
\hline & $\mathrm{n}$ & $\%$ & $\mathrm{n}$ & $\%$ \\
\hline$<$ Rp371.376 & 29 & 41,4 & 39 & $\begin{array}{l}55, \\
7\end{array}$ \\
\hline$\geq \operatorname{Rp} 371.376$ & 41 & 58,6 & 31 & $\begin{array}{l}44, \\
3\end{array}$ \\
\hline Total & 70 & 100 & 70 & $\begin{array}{l}10 \\
0\end{array}$ \\
\hline $\begin{array}{l}\text { Min-maks } \\
\text { (Rupiah) }\end{array}$ & \multicolumn{2}{|c|}{$\begin{array}{c}69.286- \\
2.583 .333\end{array}$} & \multicolumn{2}{|c|}{$\begin{array}{c}28.125- \\
3.750 .000\end{array}$} \\
\hline Rata-rata $\pm S D$ & \multicolumn{2}{|c|}{$\begin{array}{c}473.750 \pm 377 \\
.782\end{array}$} & \multicolumn{2}{|c|}{$448323 \pm 492.605$} \\
\hline
\end{tabular}

Sebaliknya, pada masa tunggu, kurang dari separuh $(38,6 \%)$ suami bekerja sebagai pedagang sementara sebagian lainnya tidak bekerja $(11,4 \%)$. Profesi lain $(48,6 \%)$ dari para suami adalah kuli bangunan, kuli angkut, sopir angkutan umum, mencari rumput untuk ternak, dan menjadi buruh kebun. Di samping itu, pada masa tunggu banyak suami yang meninggalkan desa untuk bekerja sebagai pedagang di luar kota.

Penghasilan. Lebih dari separuh pendapatan keluarga per kapita dalam satu bulan pada musim tanam berada di atas garis kemiskinan $(58,6 \%)$, yakni di atas Rp371.376. Lebih dari separuh pendapatan keluarga per kapita dalam satu bulan pada musim tunggu berada di bawah garis kemiskinan (55,7\%). Selanjutnya, pendapatan keluarga per kapita dalam satu bulan pada musim tanam jika dirata-ratakan adalah lebih besar daripada rata-rata pendapatan pada musim tunggu (Tabel 2).

\section{Pembagian Peran Gender dan Interaksi Suami-Istri}

\section{Peran Gender}

Analisis deskriptif variabel peran gender secara keseluruhan menunjukkan bahwa proporsi terbesar $(23,4 \%)$ kerja sama peran gender dilakukan oleh salah satu pihak, yaitu pada pihak istri. Selanjutnya, sebanyak 20,1 persen kerja sama peran gender dilakukan oleh salah satu pihak, yaitu pada pihak suami. Meskipun demikian, kerja sama peran gender yang dilakukan suami-istri hampir 20 persen (19,3\%). Suami-istri menyatakan dibantu oleh pihak lain, yakni 16,7 persen kerja sama peran gender dilakukan oleh pihak lainnya. Sebaliknya, proporsi kerja sama peran gender yang dominan istri (15\%) lebih tinggi jika dibandingkan dengan kerja sama peran gender yang dominan suami $(5,4 \%)$.

Domestik. Peran gender dalam ranah domestik baik pada masa tunggu maupun pada masa tanam paling banyak berada pada kategori sedang, dengan proporsi lebih dari setengah total responden. Persentase pada masa tanam lebih tinggi daripada masa tunggu. Pada masa tunggu, aktivitas domestik dikatakan paling rendah karena banyak suami yang pergi meninggalkan rumah untuk mencari nafkah sehingga mayoritas pekerjaan rumah dilakukan sendiri oleh istri atau istri dominan.

Publik. Beda halnya dengan peran gender dalam ranah domestik. Hampir seperempat peran gender dalam ranah publik pada masa tunggu berada pada kategori tinggi. Pada masa tunggu ini, persentase untuk kategori sedang lebih banyak daripada persentase pada masa tanam. Lebih dari separuh peran gender pada ranah publik terkategori sedang pada masa tunggu, sedangkan pada masa tanam persentasenya kurang dari separuh. Pada masa tunggu, suami-istri saling mencari pekerjaan sampingan dan menambah jam kerja untuk menghidupi keluarga. Sementara itu, pada masa tanam aktivitas publik seperti bekerja mencari nafkah lebih dari 8 jam dan mengelola hasil tanam dilakukan oleh orang lain sehingga menghasilkan skor nol yang lebih banyak (Tabel 3).

Sosial-Kemasyarakatan. Peran gender dalam ranah sosial-kemasyarakatan pada masa tunggu dan pada masa tanam paling banyak berada pada kategori sedang, dengan proporsi lebih dari setengah responden. Walaupun suami pergi meninggalkan desa, suami masih turut aktif dalam kegiatan-kegiatan sosial di masyarakat. Pada ranah sosialkemasyarakatan ini, kerja sama peran gender yang seimbang terkategori tinggi pada masa tanam karena suami-istri saling mengikuti kegiatan sosial di masyarakat terutama pengajian, bergotong royong, dan tolongmenolong antarwarga masyarakat jika membutuhkan bantuan.

\section{Interaksi Suami-Istri}

Komunikasi. Pada dimensi komunikasi, hampir sepertiga interaksi yang terjadi antara suamiistri responden terkategori tinggi pada masa tanam. 
Tabel 3 Sebaran responden berdasarkan peran gender masa tanam dan masa tunggu

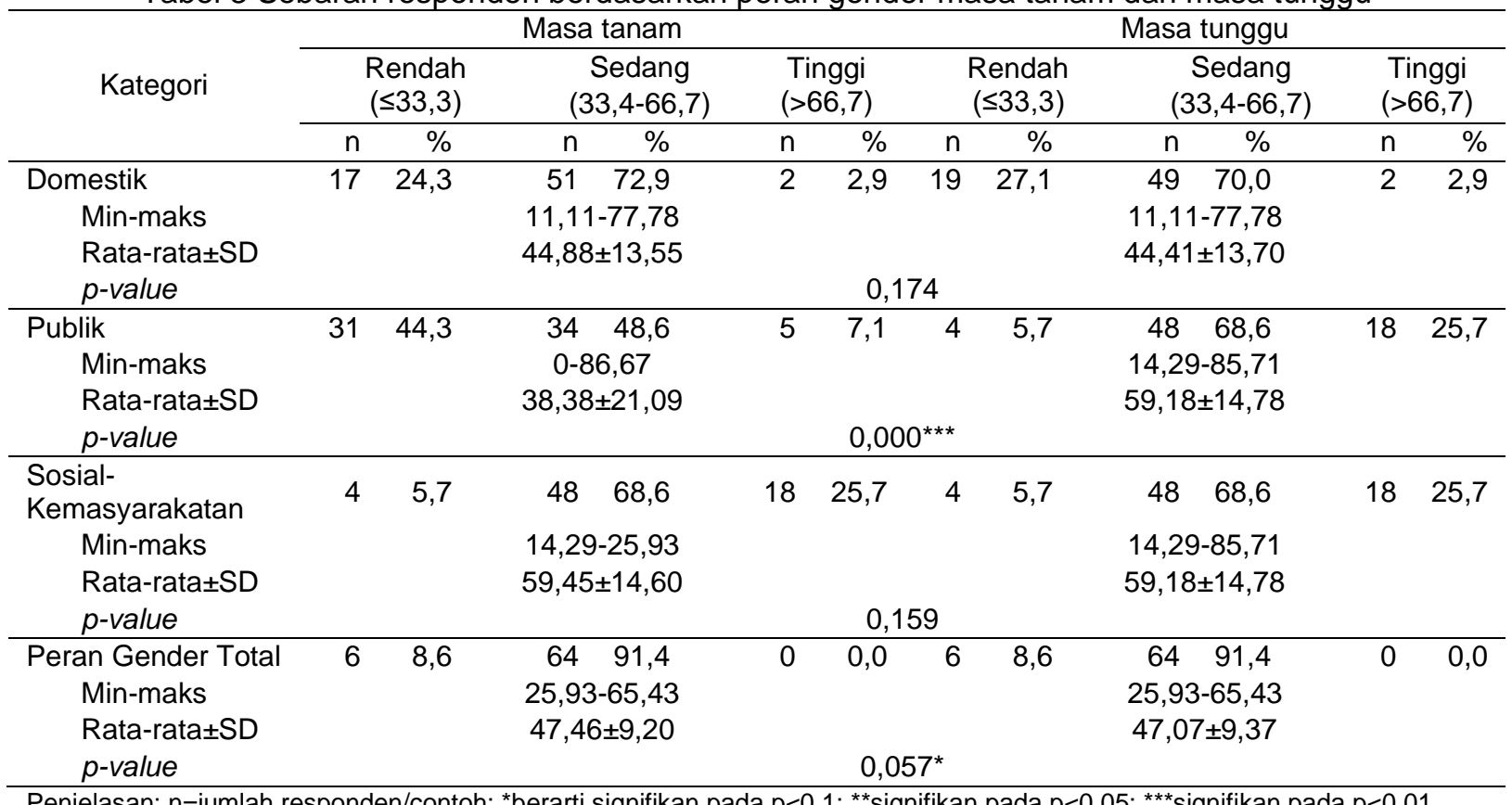

Penjelasan: $n=j u m l a h$ responden/contoh; ${ }^{*}$ berarti signifikan pada $p<0,1 ;{ }^{* *}$ signifikan pada $p<0,05 ;{ }^{* * *}$ signifikan pada $p<0,01$

Kondisi ini disebabkan kebanyakan suami-istri sama-sama bekerja sebagai petani di sawah yang sama dan memiliki waktu kerja yang sama sehingga keduanya memiliki waktu untuk berkomunikasi. Meskipun demikian, masih terdapat dimensi komunikasi yang terkategori rendah, baik pada masa tanam maupun pada masa tunggu dengan persentase yang sama $(5,7 \%)$ (Tabel 4).

Kelekatan. Sama halnya dengan dimensi komunikasi, pada dimensi kelekatan, masih terdapat interaksi suami-istri pada kategori rendah pada masa tunggu, namun tidak lebih dari 10 persen. Persentase ini mendekati 10 persen pada masa tunggu. Hal ini disebabkan banyak suami yang pergi meninggalkan desa untuk berdagang atau bekerja pada masa tunggu.

\section{Indeks Kebahagiaan dalam Keluarga Petani}

Lebih dari setengah responden $(57,1 \%)$ menunjukkan tingkat kebahagiaan terkategori sedang dan sisanya (42,9\%) terkategori tinggi. Kondisi ini terjadi karena responden tetap bersyukur dan menerima semua hal yang telah mereka miliki saat ini walaupun keluarga responden memiliki masalah ekonomi yang cukup sulit. Dengan demikian, keluarga petani dapat dikatakan bahagia dengan semua hal yang mereka miliki saat ini.

Tabel 4 Sebaran contoh berdasarkan interaksi suami istri masa tanam dan masa tunggu

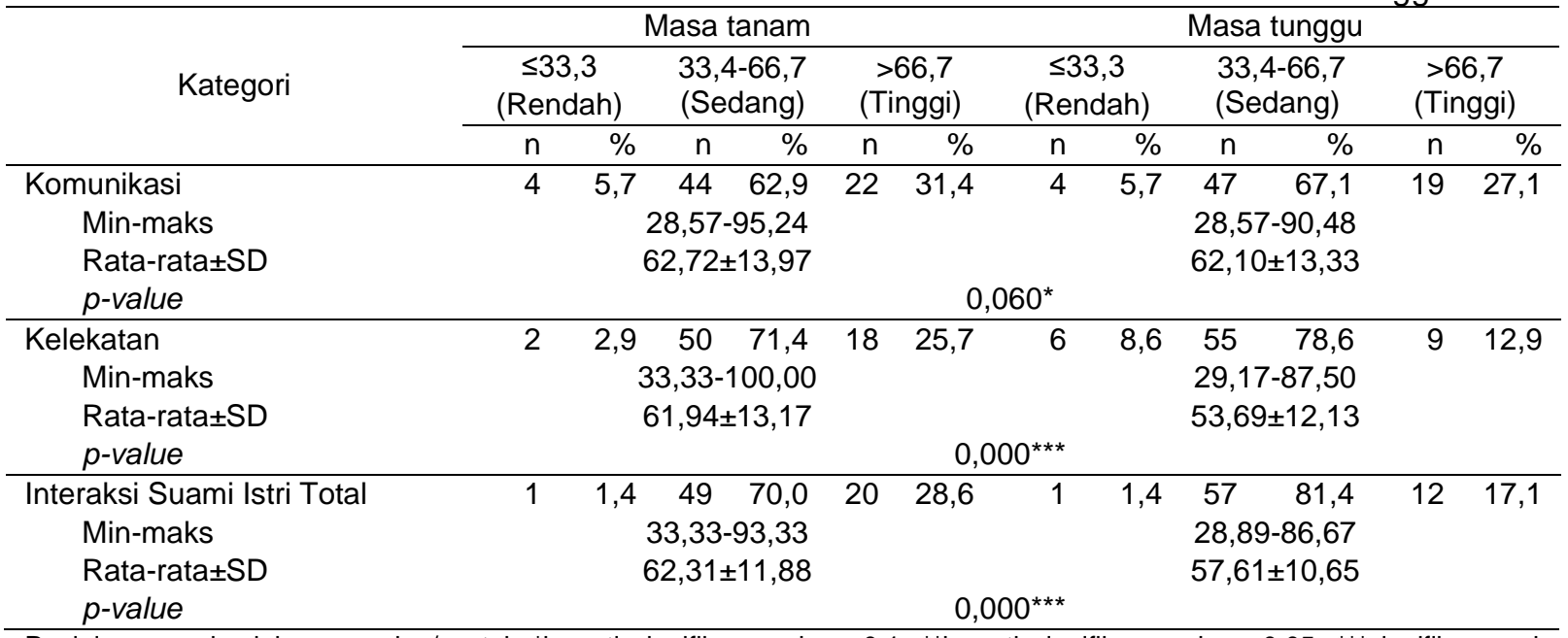

Penjelasan: $n=j u m l a h$ responden/contoh ${ }^{*}$ berarti signifikan pada $p<0,1 ;{ }^{* \star}$ berarti signifikan pada $p<0,05$; ${ }^{* \star *}$ signifikan pada $\mathrm{p}<0,01$ 


\section{Pengaruh Karakteristik Responden, Karakteristik Keluarga, Peran Gender, Interaksi Suami-Istri terhadap Indeks Kebahagiaan}

Untuk mengetahui pengaruh karakteristik keluarga, peran gender, dan interaksi suamiistri terhadap indeks kebahagiaan keluarga digunakan uji regresi linear. Pengaruh karakteristik keluarga, rerataan peran gender pada masa tanam dan masa tunggu, rerataan interaksi suami-istri pada masa tanam dan masa tunggu terhadap indeks kebahagiaan keluarga diuji dengan uji regresi linear berganda.

Pada penelitian ini, indeks kebahagiaan keluarga hanya sekali diukur dengan tidak membedakan masa tanam dan masa tunggu. Berdasarkan hasil uji pengaruh pada Tabel 5, diperoleh nilai adjusted $R^{2}$ model 0,280. Angka ini berarti bahwa variabel dalam penelitian ini hanya sebesar 28 persen memengaruhi indeks kebahagiaan, sedangkan sisanya, yakni sebanyak 72 persen, dipengaruhi variabel lain yang tidak diteliti. Selanjutnya, dari hasil uji regresi diketahui usia suami memiliki pengaruh positif signifikan terhadap indeks kebahagiaan $(B=0,203 ; p=0,014)$. Angka ini dapat diartikan bahwa keluarga dengan usia suami yang semakin tua akan memiliki indeks kebahagiaan yang juga semakin tinggi.

Tabel 5 Koefisien regresi antara karakteristik responden, karakteristik keluarga, peran gender, serta interaksi suamiistri terhadap indeks kebahagiaan

\begin{tabular}{|c|c|c|c|}
\hline \multirow{2}{*}{ Variabel } & \multicolumn{3}{|c|}{ Indeks kebahagiaan } \\
\hline & $\mathrm{B}$ & $\beta$ & Sig. \\
\hline Konstanta & 46,006 & & \\
\hline Umur istri & 0,083 & 0,106 & 0,669 \\
\hline Umur suami & 0,203 & 0,281 & $0,014^{\star *}$ \\
\hline $\begin{array}{l}\text { Lamanya } \\
\text { pendidikan istri }\end{array}$ & $-0,542$ & $-0,154$ & 0,265 \\
\hline $\begin{array}{l}\text { Lamanya } \\
\text { pendidikan suami }\end{array}$ & 0,480 & 0,148 & 0,236 \\
\hline $\begin{array}{l}\text { Pendapatan per } \\
\text { kapita keluarga }\end{array}$ & $\begin{array}{r}4,712 \mathrm{E}- \\
6\end{array}$ & 0,358 & $0,002^{* * *}$ \\
\hline Peran gender & $-0,039$ & $-0,040$ & 0,140 \\
\hline $\begin{array}{l}\text { Interaksi antara } \\
\text { suami dan istri }\end{array}$ & 0,130 & 0,198 & $0,035^{* *}$ \\
\hline Adjusted $R^{2}$ & & 0,280 & \\
\hline $\mathrm{F}$ & & 3,136 & \\
\hline Sig & & 0,009 & \\
\hline$n$ & & 70 & \\
\hline
\end{tabular}

Penjelasan: $n=$ jumlah responden; *berarti signifikan pada $\mathrm{p}<0,1 ;{ }^{* *}$ berarti signifikan pada $\mathrm{p}<0,05 ;{ }^{* \star *}$ berarti signifikan pada $p<0,01$
Pendapatan per kapita keluarga memiliki pengaruh yang positif signifikan terhadap indeks kebahagiaan ( $B=4,712 \mathrm{E}-6 ; \mathrm{p}=0,002)$. Kondisi ini berarti keluarga dengan pendapatan per kapita yang semakin tinggi akan memiliki indeks kebahagiaan yang juga semakin tinggi. Interaksi suami-istri berpengaruh positif signifikan terhadap indeks kebahagiaan $(B=$ $0,130 ; p=0,035)$. Dengan demikian, dapat diartikan bahwa keluarga dengan interaksi suami-istri yang semakin tinggi akan memiliki indeks kebahagiaan yang juga semakin tinggi.

\section{PEMBAHAAN}

Bentuk karakteristik keluarga pada penelitian ini secara umum adalah suami dan istri berusia dewasa awal. Sebanyak lebih dari sepertiga responden terkategori dewasa awal dengan persentase yang lebih banyak daripada suami. Hal ini berbeda dengan temuan Pangemanan, Memah, dan Benu (2020) dan temuan Burano dan Siska (2019) yang mana usia petani terkategori dewasa madya dengan rata-rata berusia 41-60 tahun sehigga produkstivitasnya berkurang. Petani yang berusia di atas 60 tahun bertenaga konservatif, yakni lebih mudah kelelahan. Sebaliknya, petani yang berusia lebih muda, meskipun miskin pengalaman dan keterampilan, lebih progresif serta berani dalam mengambil risiko (Burano \& Siska, 2019).

Pendidikan petani masih banyak yang rendah. Lebih dari separuh suami hanya mampu menuntaskan wajib belajar enam tahun atau tamat pendidikan dasar. Masih banyak petani hanya berpendidikan dasar (Kawengian, Mandey, \& Waney, 2019; Mandang, Sondakh, \& Laoh, 2020; Pangemanan et al., 2020; Maluhima, Memah, \& Sendow, 2020). Kondisi ini menunjukkan bahwa pendidikan petani di Indonesia masih tergolong rendah. Artinya, program Pemerintah Indonesia terkait dengan wajib belajar sembilan tahun belum maksimal di berbagai daerah. Ada dua faktor penyebab rendahnya pendidikan petani: 1) orang tua dari petani tidak memiliki kemampuan ekonomi sehingga tidak mampu menyekolahkan anakanaknya ke jenjang pendidikan yang lebih tinggi, dan 2) kesadaran petani masih rendah terhadap pentingnya pendidikan (Pangemanan et al., 2020). Pendidikan petani yang masih tergolong rendah mengakibatkan para petani mengalami kesulitan dalam menerima inovasiinovasi serta bertani dengan menggunakan teknologi (Burano \& Siska, 2019).

Menurut BKKBN (2005), besar keluarga dikelompokkan menjadi tiga kategori: keluarga 
kecil ( $\leq 4$ orang anggota); keluarga sedang (5-7 orang anggota); keluarga besar ( $\geq 8$ orang anggota). Pada penelitian ini lebih dari separuh keluarga contoh berkategori keluarga kecil dengan dua orang anak. Temuan ini juga sesuai dengan temuan Maluhima et al. (2020). Namun, masih ada petani yang merupakan keluarga besar, bahkan memiliki 14 orang anak. Adanya petani yang terkategori keluarga besar juga ditemukan Kawengian et al. (2019). Ini berarti bahwa keluarga petani tidak menerapkan program KB yang sudah dicanangkan sejak tahun 1980-an oleh Pemerintah Indonesia.

Lebih dari separuh responden memiliki pekerjaan sebagai petani pada masa tanam. Sebaliknya, pada masa tunggu lebih dari separuh responden tidak memiliki pekerjaan. Hal tersebut disebabkan responden hanya bekerja sebagai petani pada saat masa tanam dan tidak memiliki pekerjaan lain pada saat masa tunggu. Pekerjaan suami pada masa tunggu selain petani dan pedagang memiliki proporsi yang paling banyak, yakni hampir separuh. Pekerjaan selain petani dan pedagang antara lain adalah kuli bangunan, kuli angkut, sopir angkutan umum, mencari rumput untuk ternak, dan menjadi buruh kebun. Petani padi memiliki berbagai pekerjaan sampingan untuk memenuhi kebutuhan keluarganya (Harviani, Prasetyo, \& Setiawan, 2019; Mandang et al., 2020; Sejati, Abidin, \& Endaryanto, 2020; Sudalmi \& Hardiatmi, 2014; Suryandari \& Rahayuningsih, 2020; \& Umanailo, 2019) dan hal ini sama dengan petani lainnya, seperti petani kopi (Ulfa, Ngesti-S, \& Djaja, 2018). Adanya pekerjaan sampingan ini disebabkan petani membutuhkan biaya untuk sekolah anakanaknya sehingga pada masa tunggu ada yang bekerja sebagai sopir bus (Rondonuwu, 2017). Ini berarti petani tidak memiliki pendapatan pada masa tunggu untuk menyekolahkan anakanaknya.

Pendapatan per kapita pada masa tanam dan masa tunggu berada di atas garis kemiskinan Jawa Barat menurut BPS Jabar (2019). Lebih dari separuh keluarga memiliki pendapatan per kapita setiap bulan pada masa tanam di atas garis kemiskinan, sedangkan pada masa tunggu lebih dari separuh berada di bawah garis kemiskinan. Artiya, petani masih hidup dengan pendapatan di bawah UMR. Kondisi ini juga sesuai dengan temuan Listiani, Setiadi, dan Santoso (2019), yakni pendapatan petani per bulan Rp1.487.404,00 sedangkan UMR Kabupaten Jepara adalah Rp1.600.000,00. Untuk bertahan hidup dengan pendapatan di bawah UMR, petani biasanya meminjam kepada saudara, mengubah pola konsumsi agar lebih hemat, mendayagunakan lahan kosong di sekitar rumah dengan menanam sayur serta beternak unggas (Suryandari \& Rahayuningsih, 2020). Ini berarti petani mesti memiliki strategi untuk dapat bertahan hidup.

Temuan penelitian adalah ada perbedaan peran gender antara masa tanam dengan masa tunggu. Kondisi ini disebabkan perbedaan pekerjaan suami dan istri pada masa tanam dan masa tunggu sehingga terjadi perbedaan kerja sama peran gender dalam keluarga. Peran gender pada masa tanam dan masa tunggu pada dimensi domestik, publik, dan sosial kemasyarakatan berada pada kategori sedang. Suami pada masa tanam akan lebih banyak menghabiskan waktunya di rumah karena mata pencaharian utamanya adalah sebagai petani, sedangkan pada masa tunggu suami akan pergi keluar desa untuk berjualan atau mencari pekerjaan lain sehingga kerja sama peran gender akan berkurang. Berdasarkan penelitian Kiewisch (2015) diketahui bahwa peran dan relasi gender memengaruhi aktivitas produktif seseorang, kemampuan dalam mengakses sumber daya yang dibutuhkan untuk mengelola pendapatan, dan kegiatan terkait dengan pekerjaan atau profesi. Adanya perbedaan peran gender dalam pertanian disebabkan penggunaan teknologi yang tidak dapat diakses oleh perempuan (Shaliha \& Fadlia, 2019) dan jenis pekerjaan yang membutuhkan keahlian khusus, seperti pada petani bawang perempuan yang lebih banyak mencurahkan waktunya pada pembasmian gulma, pemanenan, pembersihan, serta penjemuran bawang (Samay et al., 2020). Dengan demikian, perbedaan musim, perbedaan teknologi, dan perbedaan jenis tanaman pertanian juga menyebabkan perbedaan peran gender.

Tidak hanya peran gender saja yang berbeda antara masa tanam dan masa tunggu. Perbedaan interaksi suami-istri antara masa tanam dan masa tunggu pada dimensi komunikasi dan kelekatan juga berbeda. Penyebabnya adalah pada masa tunggu banyak suami yang pergi meninggalkan rumah untuk berjualan di kota lain sehingga komunikasi dan kelekatan pada keluarga mengalami penurunan pada saat masa tunggu. Interaksi suami-istri dengan kategori tinggi paling banyak berada pada masa tanam untuk dimensi komunikasi dan kelekatan. Artinya, meskipun suami-istri sama-sama bekerja, namun lokasi dan bentuk aktivitasnya dilakukan bersama-sama sehingga memungkinkan terbentuknya komunikasi dan kelekatan yang 
tetap baik. Hal ini juga sesuai dengan temuan Srisusanti dan Zulkaida (2013) bahwa dengan adanya aktivitas bersama akan meningkatkan kelekatan dan komunikasi. Suami-istri perlu meningkatkan interaksi melalui komunikasi yang positif, kedekatan/kelekatan, saling mendukung, dan peduli (Kendhawati \& Purba, 2019). Dengan demikian, apa pun kondisi dan situasi yang dihadapi suami-istri dalam kehidupannya, mereka tetap harus menjalin komunikasi agar interaksi tetap tinggi.

Indeks kebahagiaan menjadi ukuran untuk mengetahui dan menggambarkan tingkat kesejahteraan sebab kebahagiaan adalah refleksi dari tingkat kesejahteraan yang telah diraih masing-masing individu. Kapteyn et al. (2010) serta Kahneman, Diener, dan Schwarz (1999) juga menjelaskan bahwa kebahagiaan dapat diartikan sebagai perasaan senang (feeling of pleasure) dan kepuasan terhadap sesuatu hal yang dinilai mulia (noble satisfactions). Tidak hanya itu, kebahagiaan juga dapat diartikan sebagai hal yang dirasakan seseorang atas upaya pencapaian (pursuing) dan upaya pemenuhan (fullfilling) potensi serta tujuan hidupnya (Franklin, 2010). Selanjutnya, Williams et al. (2009) mengungkapkan bahwa kebahagiaan adalah sebuah bentuk kesempurnaan maka berbagai upaya dilakukan agar hal itu tercapai.

Hasil penelitian menunjukkan bahwa keluarga petani memiliki indeks kebahagiaan yang berada pada kategori sedang dan tinggi. Walaupun keluarga responden memiliki masalah ekonomi yang cukup sulit, responden tetap bersyukur dan menerima semua yang telah mereka miliki saat ini. Hal ini dapat diartikan bahwa keluarga petani bahagia dengan segala yang mereka miliki saat ini dan menunjukkannya sebagai rasa syukur dan religi. Hal ini sesuai dengan pendapat Belliotti dalam bukunya yang diulas oleh Lemos (2004) bahwa seseorang akan bahagia jika dia menjalani kehidupannya dengan senang hati dan puas dengan situasinya.

Lebih lanjut, pendapat senada ditunjukkan oleh Zhang dan Liu (2007) bahwa kesejahteraan subjektif dipengaruhi oleh umur, gender, pendidikan, status finansial, status perkawinan, dan kesehatan fisik. Kondisi ini juga sesuai dengan temuan Rahayu (2016) bahwa faktor yang menentukan kebahagiaan di Indonesia adalah pendapatan per kapita, tingkat pendidikan, kesehatan, serta beberapa komponen modal sosial (lingkungan tempat tinggal, kepercayaan/agama/religi, rasa saling percaya).

Berdasarkan uji regresi, diketahui bahwa usia suami, pendapatan, serta interaksi antara suami dan istri memiliki pengaruh positif signifikan terhadap indeks kebahagiaan. Temuan ini dapat diartikan bahwa semakin bertambah umur suami, pendapatan, dan meningkatnya interaksi suami-istri maka tingkat kebahagiaan keluarga petani akan semakin tinggi. Hal ini sejalan dengan pendapat Zhang dan Liu (2007) bahwa kesejahteraan subjektif dipengaruhi oleh umur, gender, pendidikan, status finansial, status perkawinan, dan kesehatan fisik. Begitu pun halnya dengan semakin tinggi pendapatan per kapita, akan semakin tinggi juga tingkat kebahagiaan (Rahayu, 2016). Keluarga dengan usia suami yang semakin tinggi akan mempunyai indeks kebahagiaan yang juga semakin tinggi. Interaksi suami-istri memiliki hubungan positif signifikan dan pengaruh positif signifikan terhadap indeks kebahag iaan. Kondisi ini dapat diartikan bahwa semakin tinggi interaksi yang terjadi antara suami dan istri, semakin tinggi juga tingkat kebahagiaan suatu keluarga. Temuan ini juga sama dengan temuan Raharjo, Puspitawati, dan Krisnatuti (2015), yakni interaksi suami-istri dapat memengaruhi kesejahteraan (lahir dan batin) sebuah keluarga. Selanjutnya, Puspitawati (2012) dan Atirah (2011) juga menjelaskan bahwa kesejahteraan dipengaruhi oleh hubungan interaksi antara suami-istri. Kondisi ini disebabkan semakin seringnya tingkat komunikasi yang dilakukan, suami dan istri semakin memahami kepribadian masingmasing sehingga tingkat kebahagiaan pada keluarga tersebut semakin tinggi. Kelekatan yang dibangun antara suami-istri, seperti menyiapkan peralatan sebelum berangkat bekerja, makan bersama, dan menonton TV bersama, akan menambah kebahagiaan keluarga tersebut.

\section{SIMPULAN DAN SARAN}

Mayoritas pendidikan petani masih tergolong rendah dan penghasilan mereka pun masih banyak yang di bawah UMR. Karena mayoritas masih tergolong dewasa awal, umumnya para petani pun menekuni profesi lain seperti pedagang dan kuli pada musim tunggu agar mampu menghidupi keluarga yang umumnya tergolong keluarga kecil. Profesi sebagai petani pada musim tanam dan profesi lain pada musim tunggu masih membuat penghasilan banyak keluarga petani di bawah UMR 
sehingga banyak yang hidup di bawah garis kemiskinan, terutama pada musim tunggu. Meskipun hidup di bawah garis kemiskinan, terutama pada masa tunggu, adanya kerja sama dalam keluarga berupa pembagian peran gender untuk mewujudkan indeks kebahagiaan keluarga petani terjalin cukup baik. Bedanya profesi suami pada musim tanam dan tunggu serta tidak bekerjanya istri pada musim tunggu membuat terjadinya perbedaan peran gender. Peran gender terkategori sedang dalam ranah domestik pada masa tanam namun rendah pada masa tunggu karena suami lebih banyak meninggalkan rumah untuk bekerja sehingga pekerjaan rumah dominan dilakukan oleh satu pihak, yakni istri saja. Peran gender pada ranah publik lebih banyak yang rendah pada masa tanam daripada masa tunggu karena suami-istri disibukkan dengan pekerjaan di sawah pada masa tanam. Meskipun demikian, pada ranah sosial-kamasyarakat, peran gender berimbang pada masa tanam dan masa tunggu karena keduanya bersama-sama meluangkan waktu untuk mengkuti pengajian dan bergotong royong. Perbedaan profesi dan aktivitas suami dan istri pada musim tanam dan tunggu juga membuat tingkat interaksi berbeda pula. Interaksi antara suami dan istri terjalin dengan baik dengan kategori komunikasi dan kelekatan yang tinggi pada masa tanam karena mereka beraktivitas di tempat dan waktu yang sama, yakni sawah dan rumah. Berdasarkan uji pengaruh diketahui bahwa umur suami, interaksi suami-istri, dan pendapatan per kapita keluarga berpengaruh terhadap indeks kebahagiaan keluarga petani.

Berdasarkan hasil penelitian, saran yang dapat diberikan adalah sebagai berikut. Pertama, karena masih adanya petani yang hidup dengan penghasilan di bawah UMR, perlu dilakukan upaya pemberdayaan keluarga petani, baik oleh pemerintah maupun LSM dan perguruan tinggi, terutama pada masa tunggu sehingga mereka tidak harus meninggalkan rumah atau desanya selama berhari-hari untuk mencari pekerjaan lain. Kedua, perlu ditingkatkan kerja sama suami-istri dalam merealisasikan peran gender baik dalam ranah keluarga (domestic), publik, maupun sosialkemasyarakatan, terutama pada masa tunggu agar tidak ada pihak mana pun yang lebih dibebankan dalam melaksanakan perannya dan kebersamaan kedua pihak tetap terjalin. Ketiga, dengan adanya pengaruh interaksi suami-istri terhadap kebahagian keluarga petani, komunikasi suami-istri perlu terus ditingkatkan pada masa tunggu meskipun suami tidak melakukan aktivitas yang sama dengan istri karena perkembangan sarana komunikasi sudah semakin baik. Kelima, penelitian lanjutan disarankan untuk meneliti variabel dependen yang sama, namun variabel independen berbeda untuk melihat faktor lain yang dapat memengaruhi indeks kebahagiaan keluarga petani, melaksanakan waktu pengumpulan data dengan memperhatikan waktu bekerja responden, serta melakukan wawancara dengan kedua pasangan suami-istri agar hasil yang didapatkan menjadi semakin konkret.

\section{DAFTAR PUSTAKA}

Alfrida, A., \& Noor, T. I. (2018). Analisis pendapatan dan tingkat kesejahteraan rumah tangga petani padi sawah berdasarkan luas lahan. Jurnal IImiah Mahasiswa Agroinfo Galuh, 4(3), 803-810. doi:10.25157/jimag.v3i3.801.

Atirah. (2011). Analisis dukungan sosial, interaksi suami-istri, dan kualitas perkawinan pada keluarga tenaga kerja wanita (TKW) (Studi kasus di Desa Padaasih, Kecamatan Cisaat, Sukabumi Jawa Barat) (Skripsi). Institut Pertanian Bogor.

https://repository.ipb.ac.id/handle/1234567 89/53455.

[BKKBN] Badan Kependudukan dan Keluarga Berencana Nasional. (2005). Keluarga Berencana dan Kesehatan Reproduksi. Jakarta, ID: BKKBN.

[BPS] Badan Pusat Statistik. (2017). Indonesia: Survei Pengukuran Tingkat Kebahagiaan $2017 . \quad$ Retrieved from https://mikrodata.bps.go.id/mikrodata/index .php/catalog/809.

[BPS] Badan Pusat Statistik. (2021a). Luas Panen, Produksi, dan Produktivitas Padi Menurut Provinsi 2018-2020. Retrieved from

https://www.bps.go.id/indicator/53/1498/1/I uas-panen-produksi-dan-produktivitaspadi-menurut-provinsi.html.

[BPS] Badan Pusat Statistik. (2021b). NTPP (Nilai Tukar Petani Tanaman Pangan) Menurut Sektor. Retrieved from https://www.bps.go.id/indicator/22/1718/2/ ntpp-nilai-tukar-petani-tanaman-panganmenurut-sektor-2018-100-.html.

[BPS Jabar] Badan Pusat Statistik Jawa Barat. (2017). Tingkat Kebahagian Penduduk Jawa Barat Tahun 2017. Bandung, ID: Badan Pusat Statistik Provinsi Jawa Barat.

[BPS Jabar] Badan Pusat Statistik Jawa Barat. (2018). Luas Panen dan Produksi Padi di 
Jawa Barat 2018. Retrieved from https://jabar.bps.go.id/pressrelease/2018/1 1/01/682/luas-panen-dan-produksi-padi-dijawa-barat-2018.

[BPS Jabar] Badan Pusat Statistik Jawa Barat. (2019). Kemiskinan dan Ketimpangan di Jawa Barat. Retrieved from https://www.bps.go.id/subject/23/kemiskina n-dan-ketimpangan.html.

[BPS Kab Bogor] Badan Pusat Statistik Kabupaten Bogor. (2019). Kabupaten Bogor dalam Angka. Bogor, ID: Badan Pusat Statistik Kabupaten Bogor.

Burano, R. S., \& Siska, T. Y. (2019). Pengaruh karakteristik petani dengan pendapatan petani padi sawah. Menara IImu, 13(10), 68-74. doi:10.31869/mi.v13i10.1625.

Chuang, Y. C. (2005). Effects of interaction pattern on family harmony and well-being: Test of interpersonal theory, relationalmodels theory, and confucian ethics. Asian Journal of Social Psychology, 8(3), 272$291 . \quad$ doi:10.1111/j.1467839X.2005.00174.x.

Franklin, S. S. (2010). The Psychology Of Happiness: A Good Human Life. New York, NY: Cambridge University Press.

Harviani, B. D., Prasetyo, E., \& Setiawan, B. M. (2019). Kontribusi pendapatan usahatani padi terhadap pendapatan total rumah tangga pada petani anggota Gapoktan Tani Makmur Kecamatan Demak Kabupaten Demak. Jur. Sungkai, 7(2), 7480. doi:10.30606/js.v7i2.1777.

Herawati, T., Kumaasari, B., Musthofa, \& Tyas, F. P. S. (2018). Dukungan sosial, interaksi keluarga, dan kualitas perkawinan pada keluarga suami istri bekerja. Jur. IIm. Kel. \& Kons., 11(1), 1-12. doi:10.24156/jikk.2018.11.1.1.

Hills, P., \& Argyle, M. (2002). The Oxford happiness questionnaire: A compact scale for the measurement of psychological wellbeing. Personality and Individual Differences, 33, 1073-1082. doi:10.1016/S0191-8869(01)00213-6.

Kahneman, D., Diener, E., \& Schwarz, N. (1999). Well-being: The foundations of hedonic psychology. New York, NY: Russell Sage Foundation.

Kapteyn, A., Smith, J. P., \& Soest, A. van. (2010). Life satisfaction: International differences in well-being. New York: Oxford University Press.
Kawengian, T., Mandey, J. R., \& Waney, N. F. L. (2019). Curahan tenaga kerja pada usahatani padi di Desa Lowian Kecamatan Maesaan. Jur. Agri-Sosio-Ekonomi, 15(3), 397-406.

doi:10.35791/agrsosek.15.3.2019.25772.

Kendhawati, L., \& Purba, F. D. (2019). Hubungan kualitas pernikahan dengan kebahagiaan dan kepuasan hidup pribadi: Studi pada individu dengan usia pernikahan 1-5 tahun di Bandung. Jurnal Psikologi, 18(1), 106-115. doi:10.14710/jp.18.1.106-115.

Keumala, C. M., \& Zainuddin, Z. (2018). Indikator kesejahteraan petani melalui nilai tukar petani (NTP) dan pembiayaan syariah sebagai solusi. Economica: Jur. Ekonomi Islam, 9(1), 129-149. doi:10.21580/economica.2018.9.1.2108.

Kiewisch, E. (2015). Looking within the household: A study on gender, food security, and resilience in cocoa-growing communities. Gender \& Development, 23(3), 497-513. doi:10.1080/13552074.2015.1095550.

Krzaklewska, E. (2014). Measurement of gender equality - analysing dimensions, embracing areas, considering contexts Ewa Krzaklewska. Gender Equality \& Quality of Life - State of Art Report, 1(2), 1-33.

Lemos, J. (2004). Review reviewed work: Happiness is overrated by Raymond Angelo Belliotti. The Review of Metaphysics, 58(2), 423-425. Retrieved from

https://www.jstor.org/stable/20130457?seq =1\#metadata_info_tab_contents.

Listiani, R., Setiadi, A., \& Santoso, S. I. (2019). Analisis pendapatan usahatani pada petani padi di Kecamatan Mlonggo Kabupaten Jepara. Agrisocionomics: Jur. Sosial Ekonomi Pertanian, 3(1), 50-58. doi:10.14710/agrisocionomics.v3i1.4018.

Maluhima, S., Memah, M. Y., \& Sendow, M. M. (2020). Kontribusi usahatani padi sawah terhadap pendapatan keluarga petani di Desa Amongena li Kecamatan Langowan Timur Kabupaten Minahasa. Agrirud, 1(4), 515-523.

Mandang, M., Sondakh, M. F. L., \& Laoh, O. E. H. (2020). Karakteristik petani berlahan sempit di Desa Tolok Kecamatan Tompaso. Agri-Sosioekonomi, 16(1), 105114. 
doi:10.35791/agrsosek.16.1.2020.27131.

Matina \& Praza, R. (2018). Analisis tingkat kesejahteraan petani padi sawah di Kabupaten Aceh Utara. Agrifo, 3(2), 2734. doi:10.29103/ag.v3i2.1109.

Nurlian \& Daulay, H. (2008). Kesetaraan gender dalam pembagian kerja pada keluarga petani ladang. Harmoni Sosial, 2(2), 76-82. Retrieved from http://repository.usu.ac.id/bitstream/handle /123456789/18694/har-jan2008-2 $\% 282 \% 29$. pdf?sequence $=1$ \&isAllowed=y .

Pangemanan, E., Memah, M. Y., \& Benu, N. M. (2020). Kajian sosial ekonomi petani padi sawah di Kelurahan Taratara Ti-Ga, Kecamatan Tomohon Barat Kota Tomohon. Agrirud, 1(4), 421-425.

Puspitawati, H. (2012). Gender dan keluarga: Konsep dan realita di indonesia. Bogor, ID: IPB Press.

Puspitawati, H., Azizah, Y., Mulyana, A., \& Rahmah, A. . (2019). Relasi gender, ketahanan keluarga dan kualitas pernikahan pada keluarga nelayan dan buruh tani "brondol" bawang merah. Jur. IIm. Kel. \& Kons., 12(1), 1-12. doi:10.24156/jikk.2019.12.1.1.

Puspitawati, H., \& Fahmi, S. A. (2008). Analisis pembagian peran gender pada keluarga petani. Jur. IIm. Kel. \& Kons., 1(2), 131140. doi:10.24156/jikk.2008.1.2.131.

Puspitawati, H., \& Herawati, T. (2018). Metode Penelitian Keluarga (Revisi). Bogor, ID: IPB Press.

Raharjo, I. T., Puspitawati, H., \& Krisnatuti, D. (2015). Tekanan ekonomi, manajemen keuangan, dan kesejahteraan pada keluarga muda. Jur. IIm. Kel. \& Kons., 8(1), 38-48. doi:10.24156/jikk.2015.8.1.38.

Rahayu, T. P. (2016). Determinan kebahagiaan di Indonesia. Jurnal Ekonomi san Bisnis, 19(1), 149-170. doi:10.24914/jeb.v19i1.484.

Rondonuwu, C. O. (2017). Kehidupan petani padi di Kelurahan Tumobui Kecamatan Kotamobagu Kota Kotamobagu. Holistik, (19), 1-17

Samay, A., Susanti, E., \& Romano. (2020). Pembagian peran gender pada rumah tangga petani bawang merah. Jur. IImiah Mhs. Pertanian, 5(4), 118-124. doi:10.17969/jimfp.v5i4.15588.

Sejati, D. N., Abidin, Z., \& Endaryanto, T. (2020). Analisis risiko produksi padi dan pendapatan rumah tangga petani padi di Kampung Simpang Asam Kecamatan Banjit Kabupaten Way Kanan. Jur. IImuIImu Agribisnis (JIIA), 8(3), 525-531. doi:10.23960/jiia.v8i3.4469.

Shaliha, C. S., \& Fadlia, F. (2019). Pembagian peran gender yang tidak setara pada petani padi: Analisis kasus petani perempuan di Kabupaten Aceh Besar. Jur. IImiah Mhs. FISIP Unsyiah, 4, 1-12.

Srisusanti, S., \& Zulkaida, A. (2013). Studi deskriptif mengenai faktor-faktor yang mempengaruhi kepuasan perkawinan pada istri. Jur. Univ. Gunadharma, 1(1), 133-141.

Sudalmi, E. S., \& Hardiatmi, J. S. (2014). Ketahanan ekonomi petani dalam rangka mengatasi gagal panen padi di Desa Sidoharjo Kecamatan Sidoharjo Kabupaten Sragen. Joglo, 26(1).

Sunarti, E., \& Khomsan, A. (2006). Kesejahteraan Keluarga Petani, Mengapa Sulit Diwujudkan. Bogor, ID: Institut Pertanian Bogor.

Suryadi, R., \& Fathurrahman, A. (2019). FaktorFaktor yang mempengaruhi minat petani dalam menggunakan pembiayaan AsSalam pada perbankan syariah. Journal of Economics Research and Social Sciences, 3(1), 19-30. doi:10.18196/jerss.030103.

Suryandari, A., \& Rahayuningsih, E. S. (2020). Strategi bertahan hidup ekonomi rumah tangga petani padi (Studi kasus di DesaTonjung Kecamatan Burneh Kabupaten Bangkalan). Pamator, 13(2), 176-182. doi:10.21107/pamator.v13i2.8525.

Ulfa, E. A., Ngesti-S, R., \& Djaja, S. (2018). Upaya pemenuhan kebutuhan hidup petani kopi di Desa Harjomulyo Kecamatan Silo Kabupaten Jember. JPE: Jur. Pddk Ekonomi (Jur. IImiah IImu Pendidikan, IImu Ekonomi san IImu Sosial), 12(1), 116-121. doi:10.19184/jpe.v12i1.7619.

Umanailo, M. C. B. (2019). Strategi bertahan hidup petani padi gogo di Pulau Buru. Jur. Ekonomi Pertanian \& Agribisnis, 3(1), 5058. doi:10.21776/ub.jepa.2019.003.01.6

Wheatley, D. (2014). Travel to work and subjective well being: A study of UK dual career households. Journal of Transport Geography, 39(July), 187-196. doi:10.1016/j.jtrangeo.2014.07.009.

Williams, K. B., Sawyer, C. S., \& Wahlstrom, M. 
C. (2009). Marriages, Families, Intimate Relationship: A Practical Introduction. Boston, MA: Pearson Education, Inc.

Yeni, F. (2013). Dinamika komunikasi antar pasangan. NERS: Jurnal Keperawatan, 9(2), 103-109. doi:10.25077/njk.9.2.109-
115.2013.

Zhang, W., \& Liu, G. (2007). Childlessness, psychological well-being, and life satisfaction among the elderly in China. Jour. of Cross-Cultural Gerontology, 22(2), 185-203. doi:10.1007/s10823-007-9037-3. 